\title{
Helminth Infection in Primary School Children and Characteristics of Settlement in The Coastal Village of Kusan Hilir Subdistrict Tanah Bumbu District, South Kalimantan Province, Indonesia
}

\author{
${ }^{* 1}$ Budi Hairani, ${ }^{1}$ Syarif Hidayat, ${ }^{1}$ Juhairiyah, ${ }^{1}$ Liestiana Indriyati \\ ${ }^{I}$ National Agency on Health Research and Development, Tanah Bumbu, Indonesia \\ "Email: budihaira@gmail.com
}

\begin{abstract}
Environmental factors are very influential in the transmission of helminthiasis. This study aimed to determine the prevalence of helminthiasis in primary school-aged children living in villages with coastal ecosystem types in Kusan Hilir Sub-district, Tanah Bumbu District. Furthermore, we ought to identify and compare the characteristics of settlement areas that may increase the risk of transmission. This cross-sectional study was conducted in February of 2016 with three sampling areas selected purposively (Sepunggur, Juku Eja, and Sungai Lembu Village). Prevalence of helminthiasis was determined by examination of stool samples from primary school-age children (6-15 years old in Indonesia) in selected villages. Characteristics of settlements observed were settlement density, permanence of buildings, availability of public toilets, and the physical environmental characteristics of soil types. Prevalence of helminth infection were as follows: Juku Eja Village (82.93\%), Sungai Lembu Village $(24.44 \%)$, and Sepunggur Village (6.04\%). Helminth species found were varies from Soil Transmitted Helminth (STH) to non-STH groups. Juku Eja Village has the most settlement characteristics that support the transmission of helminth. In order to decrease the risk of transmission, it is crucial to improve the infrastructure of villages such as paving, providing public hand-wash facilities, warning sign persuading not to defecate on the beach, and construction of clean green open space as a playground for children. Mass drug administration for the population needs to be done along with health monitoring (especially helminth infection in children) on an ongoing basis.
\end{abstract}

Indexed terms- helminthiasis, characteristics of settlement, coastal

\section{INTRODUCTION}

Indonesia still struggling to overcome high prevalence of helminth infections [1]. To date, helminthiasis is considered as less important disease, hence this disease draw less priority in disease prevention program by the local government. Chronic helminthiasis did not cause clear clinical symptoms and their effects are only seen in the long term such as malnutrition, growth disorders and cognitive impairment in children [2,3]. This disease inflicted considerable losses in financial terms [4] Pre-school children and school-age (0 - 15 years old) are groups with the risk of infection [5,6].

Helminthiasis is closely related to environmental characteristics [7]. The incidence rate of helminth infections is generally higher in areas of poorly sanitary settlements [8]. Characteristics of settlements in areas closest to coastal areas generally have densely populated buildings or houses, poor neighborhoods and poor sanitation, and a limited source of clean water $[9,10]$.

Tanah Bumbu is one of the districts in South Kalimantan that has the longest coastline area with coastal ecosystem. Many residents found residing in the shoreline areas, particularly in the area of Kusan Hilir. Result from research of Loka Litbang P2B2 Tanah Bumbu in 2008-2009 found that Tanah Bumbu was one of the districts in South Kalimantan with highest helminthiasis incidences [11]. However, this result only reflected to general value of helminthiasis in Tanah Bumbu, there were no specific data on the level of helminthiasis prevalence that are specifically focused on vulnerable areas such as coastal settlements.

The World Health Organization (WHO) has targeted to eliminate STH infection which is a public health problem especially in children by year 2020 [12]. Indonesia as an endemic area, has a 
responsibility in supporting the achievement of WHO targets by implementing helminthiasis control programs. Factual data of helminthiasis prevalence at a certain environmental characteristic is needed to formulate a helminthiasis control policy in accordance with certain environmental characteristics. Therefore, this study aimed to determine the prevalence of worms in primary school-aged children living in villages with coastal ecosystem types in Kusan Hilir Sub-district, Tanah Bumbu district. Furthermore, we ought to identify and compare the characteristics of residential areas that may increase the risk of helminth infection in the village where the child lives.

\section{METHODOLOGY}

A descriptive research with cross-sectional design was conducted in February 2016. The analysis unit was village area which determined purposively with following criteria: 1) belong to the Kusan Hilir subdistrict; 2) having the type of coastal ecosystem, and; 3) there is at least 1 elementary school. Based on these criteria, the selected villages were Sepunggur, Juku Eja, and Sungai Lembu Village. Objects studied in each unit of analysis were the characteristics of settlements including density of settlements, type of buildings (permanent or not), availability of public toilet facilities, as well as physical environmental characteristics of soil type.

Prevalence of helminthiasis was determined by examination of stool samples.[4,13] Stool sampling was conducted on elementary school age children (6-15 years old) in each selected village. Stool collection from children was done in school by giving stool pot with explanation on how to take the stool and put it into the pot (Figure 1). The distribution of pots was supplemented with informed consent to obtain approval from the child's parents. Pots were collected for maximum two days after distribution. Stool examination was done at the Parasitology Laboratory of Balai P2B2 Tanah Bumbu by native method (direct) with 2 repetitions.

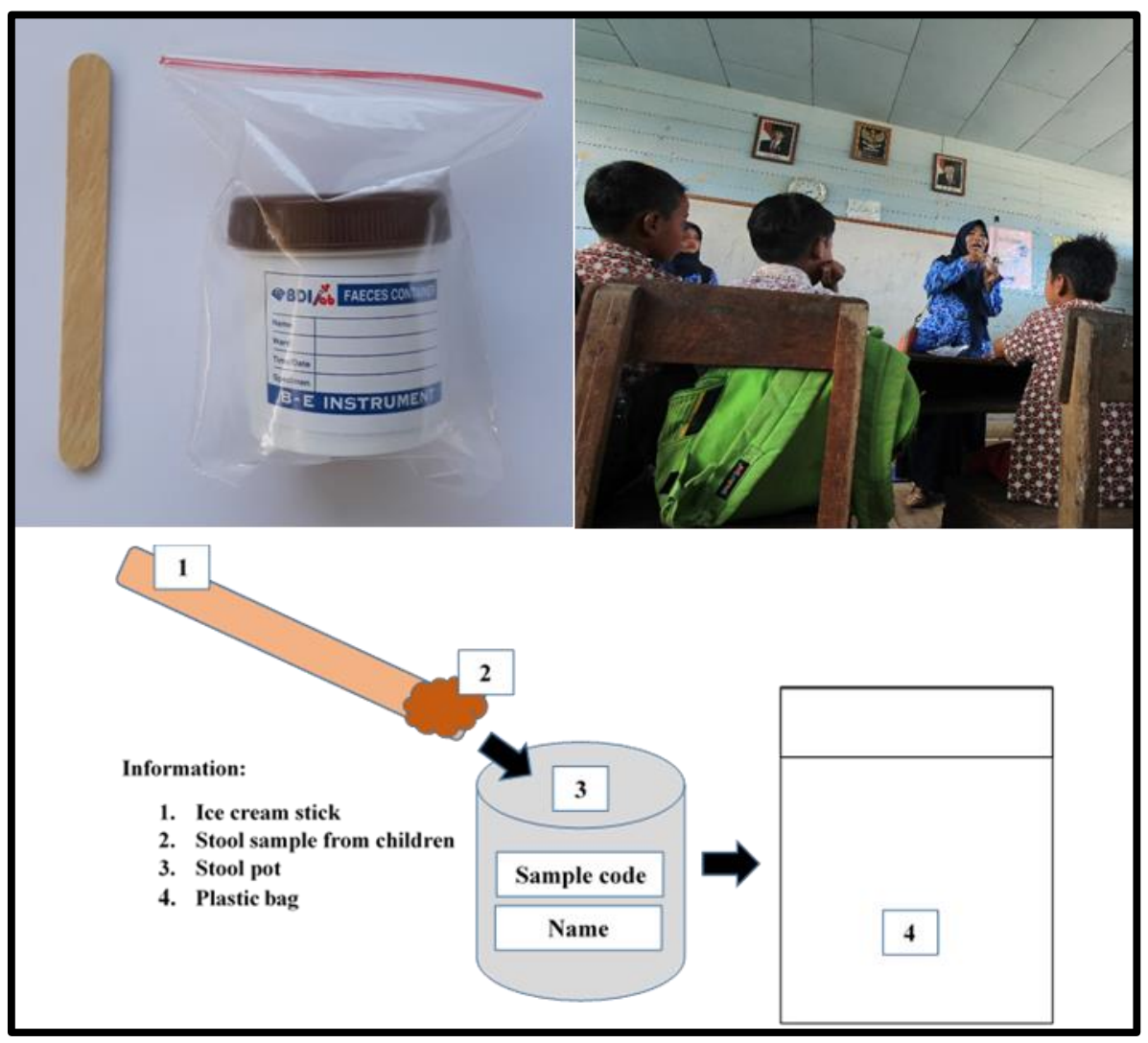

Figure 1: Collection of stool samples from elementary school children (Left. Pot and stick used to take the stool; Right. Research member explain the instruction to use the sampling kit; Below. llustration of specimen collecting 


\section{RESULTS AND DISCUSSIONS}

\subsection{Stool examination}

We have collected 362 stool pots from 464 pots distributed. In addition, 94 children did not collect the pots for variable reasons such as: did not defecate; ashamed, and; absent from school, while as many as 8 pots contain only liquids. There were 133 samples positive for helminthiasis. The highest prevalence was in Juku Eja Village (82.93\%), while the lowest prevalence was Sepunggur Village (6.04\%). Type of helminth found were varied widely (Table 1).

Table 1: Microscopic Examination Result of Stool Samples from Primary School Children in Sepunggur, Juku Eja, and Sungai Lembu Village

\begin{tabular}{|c|c|c|c|c|}
\hline Result & $\begin{array}{c}\text { Sepunggur } \\
(\mathrm{N}=149)\end{array}$ & $\begin{array}{l}\text { Juku Eja } \\
(\mathrm{N}=\mathbf{1 2 3})\end{array}$ & $\begin{array}{c}\text { Sungai Lembu } \\
(\mathrm{N}=90)\end{array}$ & $\begin{array}{c}\text { Total } \\
(\mathrm{N}=362) \\
\end{array}$ \\
\hline Negative & $140(93.96 \%)$ & $21(17.07 \%)$ & $68(75.56 \%)$ & $229(63.26 \%)$ \\
\hline Positive & $9(6.04 \%)$ & $102(82.93 \%)$ & $22(24.44 \%)$ & $133(36.74 \%)$ \\
\hline \multicolumn{5}{|c|}{ A. Single species positive } \\
\hline$-T t$ & 5 & 44 & 17 & 66 \\
\hline$-A l$ & - & - & 3 & 3 \\
\hline$-E v$ & 1 & - & - & 1 \\
\hline$-H d$ & 1 & 1 & - & 2 \\
\hline \multicolumn{5}{|c|}{ B. Two species mix positive } \\
\hline - Tt and Ev & 2 & - & - & 2 \\
\hline - Al and $T t$ & - & 35 & 1 & 36 \\
\hline - Al and $H n$ & - & 1 & - & 1 \\
\hline - Tt and Hn & - & 4 & 1 & 5 \\
\hline - Tt and $H w$ & - & 5 & - & 5 \\
\hline \multicolumn{5}{|c|}{ C. Three species mix positive } \\
\hline - Al, Tt and $\mathrm{Hn}$ & - & 3 & - & 3 \\
\hline - Al, Tt and $H w$ & - & 7 & - & 7 \\
\hline - Al, Tt and $H d$ & - & 1 & - & 1 \\
\hline - Al, Tt and $E v$ & - & 1 & - & 1 \\
\hline
\end{tabular}

$\begin{array}{ll}\text { Species abbreviation: } \\ \mathrm{Tt} & \text { : Trichuris trichiura } \\ \mathrm{Al} & \text { : Ascaris lumbriciodes } \\ \mathrm{Hw} & : \text { Hookworm } \\ \mathrm{Ev} & \text { : Enterobius vermicularis } \\ \mathrm{Hd} & \text { : Hymenolepis diminuta } \\ \mathrm{Hn} & \text { : Hymenolepis nana }\end{array}$

Helminthiasis is an infectious disease closely related to the environmental characteristics of the patient [7]. WHO has categorized areas with prevalence of helminthiasis more than 50\% as high risk areas, prevalence of helminthiasis between $20 \%$ and $<50 \%$ as moderate areas, and prevalence less than $20 \%$ as low risk areas [12]. Based on the categories of WHO, Juku Eja Village (82.93\%) can be classified as high risk area, Sungai Lembu Village (24.44\%) as medium risk area, and Sepunggur Village (6.04\%) as low risk area. Data analysis on previously published articles has significant differences for the prevalence of worms in each village [14]. Quality of settlements was closely related to the health status of the population [15-17]. Generally, residential characteristic in the three villages that were assumed to affect directly or indirectly the level of helminth infection were population density, level of permanent building, distance to the shoreline, geographical conditions (dominant soil types), and facilities and infrastructure (availability of public toilets). 


\subsection{Characteristic of settlement}

The data of settlement characteristic of the three villages presented below (Table 2). Data was obtained based on secondary source search from Central Bureau of Statistics (BPS [Badan Pusat Statistik]; INA) of Tanah Bumbu District and based on direct observations in the field.

Table 2: Characteristic of settlement in Sepunggur, Juku Eja, and Sungai Lembu Village

\begin{tabular}{lccc}
\hline \multicolumn{1}{c}{ Characteristic of settlement } & Sepunggur & Juku Eja & Sungai Lembu \\
\hline Population density (person/ $\left./ \mathrm{km}^{2}\right)$ & 98.90 & 2600 & 229.81 \\
Percentage of permanent house & $90 \%$ & $60 \%$ & $90 \%$ \\
Public toilet & None & Present, unused & Present, used \\
Distance to the shoreline (m) & $>500$ & $<100$ & $<100$ \\
Type of soil around & Clay and loose soil & Sandy soil & Sandy soil \\
\hline
\end{tabular}

In general, the rate of disease transmission including helminthiasis will be higher in an area with high population density $[18,19]$. Juku Eja Village was the smallest area among the three sampling villages (Figure 1), however great population number resulting its population density very high compared to the other two villages. Its high density made it difficult to find open space in Juku Eja Village, limiting the activities and movement of people including the children. The only open space was the coastal edges that becomes the choice of the children to play. Transmission of helminth will occur if the soil on the land is contaminated with helminth eggs. Higher intensity of activity and the number of children playing on the area could lead to helminthiasis transmission.

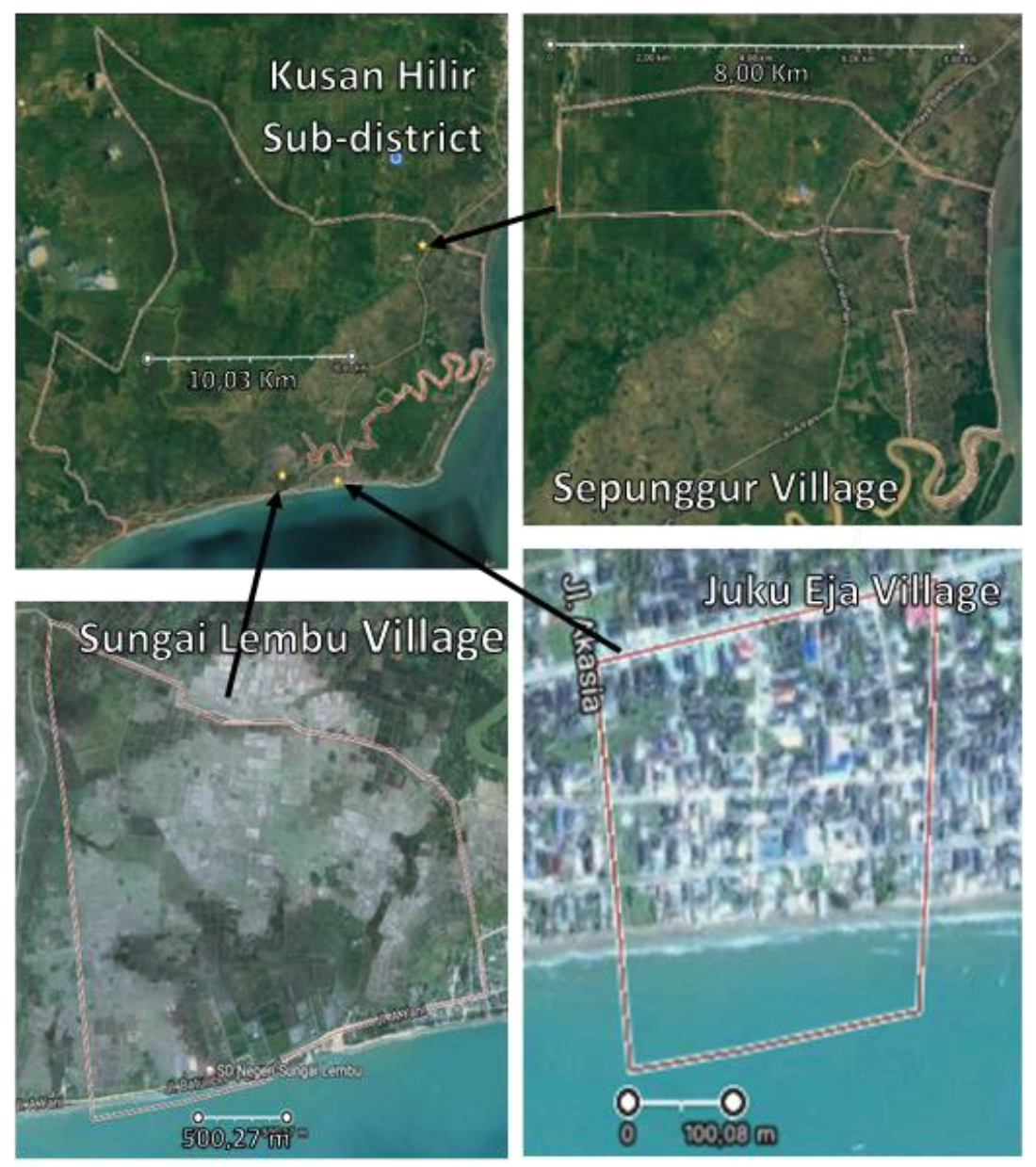

Figure 2: Map of Kusan Hilir Sub-district, Sepunggur Village, Sungai Lembu Village, and Juku Eja Village (Source: Google Maps) 
Sanitation problems based on geographical and topographic factors typical of coastal areas were often aggravated by population settlements that did not refer to the correct spatial layout [9]. The number of permanent house building can serve as a scale for the quality of the settlements. The more nonpermanent buildings indicate the lower quality of settlements [10]. Sepunggur and Sungai Lembu villages have a higher proportion of permanent house buildings and already indoor toilet. Nonpermanent buildings in Juku Eja were generally rented-house or small wooden houses, mostly without toilet facilities. Most residents only rent, and did not own the building. The status of non-owner occupants makes them reluctant to simply provide the house with proper toilet. The absence of toilets in these house then shaping the behavior of some residents to defecate anywhere they like.

To improve the quality of environmental sanitation, the local government has built public toilet facilities in several villages. There was no public toilet in Sepunggur Village, however people in this village have had their private toilet at the house. Public toilets were available in both Juku Eja and Sungai Lembu Village, but only people in Sungai Lembu Village that utilizing the toilet. Condition of public toilet facilities in Juku Eja Village were not maintained and were not utilized because some residents prefer to defecate in the beach.

Beside the absence of indoor toilets, the behavior of people in Juku Eja to defecate on the beach were also influenced by the proximity of the settlement to the beach. Settlements in Juku Eja and Lembu River Villages were close to the coast, but Lembu River Village was passed by provincial highway that separate the settlement with the shoreline (Figure 1). Furthermore, the highway was a coastal tourist area, so that its cleanliness receives more responsiveness from the local government. This barrier presumably can limit the activities of residents to dispose of garbage and defecate on the beach. The settlements in Juku Eja Village was situated directly (no boundaries) with the beach, so that the population freely use the beach as a place to defecate and throwing garbage. Some of the human stool that was dumped on the beach will be wiped out so that become closer to the residential area. If the stool contains helminth eggs, then this will be a source of new infections, especially for children who often play there. This condition was likely to cause high prevalence of helminthiasis in Juku Eja Village compared to other villages.

Soil type in the three villages was suitable for the development of helminth eggs into larvae that can infect humans. Most of helminth infections found were Soil Transmitted Helminth (STH) group: Trichuris trichiura; Ascaris lumbricoides; and Hookworm. Within their life cycle, those helminth live and lay eggs in human intestine. These eggs exited along with the stools of their host and mature (become infective) in the soil [20]. This support the assumption that helminth transmission was more dominant due to human contact with soil contaminated by helminth eggs.

Aside from the STH group, we also found non-STH group infections (life cycle to infective form did not require soil as media) which are Enterobius vermicularis, Hymenolepis nana, and Hymenolepis diminuta. This infection was found in all sampling villages, but found mostly in Juku Eja Village. $E$. vermicularis infections were commonly found in low socioeconomic areas with shortage of environmental conditions and poor personal hygiene [21,22]. There was a strong correlation between hand and nail hygiene with Enterobiasis incidences. One of the E. vermicularis transmission methods was autoinfection from person's hand into their own mouth or by holding objects contaminated by infective E. vermicularis eggs [23].

Source of Hymenolepis transmission can be from human and mouse stools containing helminth eggs. Either human or rodent acts as the definitive host, while arthropods such as beetles (Tenebrio and Tribolium) or lice (Ctenocephalides, Xenopsylla, Pulex) act as the intermediate hosts [24]. Rattus norvegicus and Rattus tanezumi were well-adaptable rats in human life activities and commonly found in settlements with poor environmental sanitation conditions. High rat population is a risk factor for the transmission of disease brought by rats [25]. The poor condition of settlement and environmental sanitation in Juku Eja Village becomes a good inhabitance for rats, this was supported by the founding of rat carcasses in several locations. Poor environment condition in Juku Eja Village was shown by our result where many of infected children were infected by two species of helminth. Furthermore, three species-mixed infections was found only in children from Juku Eja Village. 


\section{CONCLUSIONS}

It can be concluded that Juku Eja Village has the highest prevalence of helminthiasis and has the most settlement characteristic supporting the risk of helminth infection compared to the other villages. Characteristics of existing settlements might form a habit that worsens the risk of helminth infection to its residents.

It is suggested that the local government should make improvements of infrastructure that can reduce the risk of helminth infection such as ground paving, public hand-washing facilities, health promotion billboard to encourage people avoiding defecate on the beach, and building clean green open spaces as a playground for children. Mass drug administration need to be done simultaneously with health surveillance (particularly examination of helminth in children) on an ongoing basis.

\section{ACKNOWLEDGEMENTS}

The authors would like to thank Dicky Andiarsa, M.Ked (Vet.) for advice and guidance in writing this manuscript. We also thank to the village headman, principal and teachers of primary school at the research sites, laboratory analysts and researchers in Parasitology Laboratory of Balai Litbangkes Tanah Bumbu who have participated in the helminth and environmental survey.

\section{REFERENCES}

[1] Rawina Winita, Mulyati HA. Upaya pemberantasan kecacingan Di sekolah dasar. J Makara Kesehat 2012;16:65-71.

[2] Kurniawan A. Infeksi Parasit: Dulu dan Masa Kini. Maj Kedokt Indones 2010;60:487-8.

[3] Müller I, Coulibaly JT, Fürst T, Knopp S, Hattendorf J, Krauth SJ, et al. Effect of schistosomiasis and soil-transmitted helminth infections on physical fitness of school children in côte d'ivoire. PLoS Negl Trop Dis 2011;5. doi:10.1371/journal.pntd.0001239.

[4] Indriyati L, Waris L, Luciasari E. Kerugian finansial akibat kecacingan: studi di Kabupaten Nunukan. Penel Gizi Makan 2014;37:155-60.

[5] Belizario VY, Totañes FIG, De Leon WU, Ciro RNT, Lumampao YF. Sentinel surveillance of soil-transmitted helminthiasis in preschool-aged and school-aged children in selected local government units in the Philippines: Follow-up assessment. Asia-Pacific J Public Heal 2015;27:NP1604-NP1615. doi:10.1177/1010539513483825.

[6] Kounnavong S, Vonglokham M, Houamboun K, Odermatt P, Boupha B. Soil-transmitted helminth infections and risk factors in preschool children in southern rural Lao People's Democratic Republic. Trans R Soc Trop Med Hyg 2011;105:160-6. doi:10.1016/j.trstmh.2010.11.011.

[7] Ziegelbauer K, Speich B, Mäusezahl D, Bos R, Keiser J, Utzinger J. Effect of sanitation on soil-transmitted helminth infection: Systematic review and meta-analysis. PLoS Med 2012;9. doi:10.1371/journal.pmed.1001162.

[8] Campbell SJ, Savage GB, Gray DJ, Atkinson JAM, Soares Magalhães RJ, Nery S V., et al. Water, Sanitation, and Hygiene (WASH): A Critical Component for Sustainable SoilTransmitted Helminth and Schistosomiasis Control. PLoS Negl Trop Dis 2014;8:1-5. doi:10.1371/journal.pntd.0002651.

[9] Astono W. Problem Sanitasi , Karakteristik Sosial Ekonomi dan Upaya Pemberdayaan Masyarakat Nelayan. J Ekosains 2010;II:1-5.

[10] Marwasta D, Priyono KD. Analisis Karakteristik Permukiman Desa-Desa Pesisir di Kabupaten Kulonprogo. Forum Geogr 2007;21:57-68.

[11] Annida; Fakhrizal, Deni; Waris, Lukman; Rahayu N. Pola distribusi himenolepiasis di Kalimantan Selatan. J Buski 2012;4:23-8.

[12] World Health Organization. Soil-Transmitted Helminthiases: Eliminating Soil-Transmitted 
Helmnthiases as a Public Health Problem in Children. Prog Rep 2012:1-90.

[13] Tangel F, Tuda, Josep S.BPijoh VD. Infeksi parasit usus pada anak sekolah dasar di pesisir pantai Kecamatan Wori Kabupaten Minahasa Utara. J e-Biomedik 2016;4:70-5.

[14] Paisal, Hairani B, Hariyati E, Indriyati L. Dampak tingginya prevalensi Trichuris trichiura terhadap kebijakan pengobatan massal kecacingan di tiga SD di Kabupaten Tanah Bumbu. J Kebijak Pembang 2017;12:77-83.

[15] Govender T, Barnes JM, Pieper CH. Housing conditions, sanitation status and associated health risks in selected subsidized low-cost housing settlements in Cape Town, South Africa. Habitat Int 2011;35:335-42. doi:https://doi.org/10.1016/j.habitatint.2010.11.001.

[16] Zulu EM, Beguy D, Ezeh AC, Bocquier P, Madise NJ, Cleland J, et al. Overview of migration, poverty and health dynamics in Nairobi City's slum settlements. J Urban Heal 2011;88:185-99. doi:10.1007/s11524-011-9595-0.

[17] Bellows B, Kyobutungi C, Mutua MK, Warren C, Ezeh A. Increase in facility-based deliveries associated with a maternal health voucher programme in informal settlements in Nairobi, Kenya. Health Policy Plan 2013;28:134-42. doi:10.1093/heapol/czs030.

[18] Koroma JB, Peterson J, Gbakima AA, Nylander FE, Sahr F, Magalhães RJS, et al. Geographical distribution of intestinal schistosomiasis and soil-transmitted helminthiasis and preventive chemotherapy strategies in Sierra Leone. PLoS Negl Trop Dis 2010;4. doi:10.1371/journal.pntd.0000891.

[19] Semuel Sandy, Sri Sumarni S. Analisis Model Faktor Risiko Yang Mempengaruhi Infeksi Kecacingan Yang Ditularkan Melalui Tanah Pada Siswa Sekolah Dasar Di Distrik Arso Kabupaten Keerom, Papua. Media Penelit Dan Pengemb Kesehat 2015;25:1-14.

[20] Hairani B. Keberadaan Telur dan Larva Cacing Tambang pada Tanah di Lingkungan Desa Sepunggur dan Desa Gunung Tinggi Kabupaten Tanah Bumbu Kalimantan Selatan Tahun 2014 2015;9:15-20.

[21] Bunchu N, Vitta A, Thongwat D, Lamlertthon S, Pimolsri U, Waree P, et al. Enterobius vermicularis Infection among Children in Lower Northern Thailand 2011;34:36-40.

[22] Cranston I, Potgieter N, Mathebula S, Ensink JHJ. Transmission of Enterobius vermicularis eggs through hands of school children in rural South Africa. Acta Trop 2015;150:94-6. doi:https://doi.org/10.1016/j.actatropica.2015.07.001.

[23] Perdana AS, Keman S. Hubungan Higiene Tangan dan Kuku dengan Kejadian Enterobiasis Pada Siswa Sdn Kenjeran No . 248 Kecamatan Bulak Surabaya. Kesehat Lingkung 2013;7:713.

[24] Alvarez-Fernandez BE, Rodrfguez-Bataz E, Dfaz-Chiguer DL. Mixed Hymenolepis species infection in two family members: a case report from an urban area of Chilpancingo, Guerrero, México. Trop Gastroenterol 2012;33:83-4. doi:10.7869/tg.2012.20.

[25] Mulyono A, Ristiyanto, Rahardianingtyas E, Putro WD., Joharina SA. Prevalensi Dan Identifikasi Leptospira Patogenik Pada Tikus Komensal Di Kota Maumere, Flores. Vektora 2016;8:31-40. 